\title{
Water and sediment fluxes in Mediterranean mountainous regions: comprehensive dataset for hydro-sedimentological analyses and modelling in a mesoscale catchment (River Isábena, NE Spain)
}

\author{
Till Francke $^{1}$, Saskia Foerster ${ }^{2}$, Arlena Brosinsky ${ }^{1,2}$, Erik Sommerer ${ }^{7}$, Jose A. Lopez-Tarazon ${ }^{1,3,4}$, \\ Andreas Güntner ${ }^{7,1}$, Ramon J. Batalla ${ }^{4,5,6}$, and Axel Bronstert ${ }^{1}$ \\ ${ }^{1}$ University of Potsdam, Institute of Earth and Environmental Science, Karl-Liebknecht-Str. 24-25, \\ 14476 Potsdam, Germany \\ ${ }^{2}$ GFZ German Research Centre for Geosciences, Section 1.4 Remote Sensing, Telegrafenberg, \\ 14473 Potsdam, Germany \\ ${ }^{3}$ Mediterranean Ecogeomorphological and Hydrological Connectivity Research Team (MEDhyCON), \\ Department of Geography, University of the Balearic Islands, 07122 Palma, Spain \\ ${ }^{4}$ RIUS, Fluvial Dynamics Research Group, University of Lleida, 25198 Lleida, Catalonia, Spain \\ ${ }^{5}$ Catalan Institute for Water Research, 17003 Girona, Catalonia, Spain \\ ${ }^{6}$ Faculty of Forest Sciences and Natural Resources, Universidad Austral de Chile, Valdivia, Chile \\ ${ }^{7}$ GFZ German Research Centre for Geosciences, Section 5.4 Hydrology, Telegrafenberg, \\ 14473 Potsdam, Germany
}

Correspondence: Till Francke (francke@ uni-potsdam.de)

Received: 11 July 2017 - Discussion started: 6 November 2017

Revised: 15 May 2018 - Accepted: 22 May 2018 - Published: 14 June 2018

\begin{abstract}
A comprehensive hydro-sedimentological dataset for the Isábena catchment, northeastern (NE) Spain, for the period 2010-2018 is presented to analyse water and sediment fluxes in a Mediterranean mesoscale catchment. The dataset includes rainfall data from 12 rain gauges distributed within the study area complemented by meteorological data of 12 official meteo-stations. It comprises discharge data derived from water stage measurements as well as suspended sediment concentrations (SSCs) at six gauging stations of the River Isábena and its sub-catchments. Soil spectroscopic data from 351 suspended sediment samples and 152 soil samples were collected to characterize sediment source regions and sediment properties via fingerprinting analyses. The Isábena catchment $\left(445 \mathrm{~km}^{2}\right)$ is located in the southern central Pyrenees ranging from $450 \mathrm{~m}$ to $2720 \mathrm{~m}$ a.s.l.; together with a pronounced topography, this leads to distinct temperature and precipitation gradients. The River Isábena shows marked discharge variations and high sediment yields causing severe siltation problems in the downstream Barasona Reservoir. The main sediment source is badland areas located on Eocene marls that are well connected to the river network. The dataset features a comprehensive set of variables in a high spatial and temporal resolution suitable for the advanced process understanding of water and sediment fluxes, their origin and connectivity and sediment budgeting and for the evaluation and further development of hydro-sedimentological models in Mediterranean mesoscale mountainous catchments.
\end{abstract}

The dataset is available at http://doi.org/10.5880/fidgeo.2018.011. 


\section{Introduction}

Many dryland regions experience strong erosion in headwater catchments, resulting in reservoir sedimentation and a loss of storage volume that can lead to a significant reduction of water availability within a few decades. This calls for a thorough analysis of water and sediment fluxes in regions affected by high erosion and sediment delivery rates as a prerequisite for sustainable water and sediment management. Management decisions should ideally be based on in-depth analyses and modelling with the aim to improve the understanding of water and sediment fluxes and the connectivity of landscape compartments, as well as the origins of sediments. For this purpose, long-term, consistent multi-scale measurements are needed. There is, however, a lack of comprehensive high-resolution, multi-year hydro-sedimentological datasets due to the enormous effort of running measurement programmes, particularly in mountainous regions. Furthermore, publication of comparable datasets has been done rather dilatorily in the past. Notable exceptions include the datasets by Goodrich et al. (2008), Nichols et al. (2008) and Stone et al. (2008) (hydro-meteo-sedimentological data of small semiarid catchments, Arizona, USA), Nord et al. (2017) (hydro-meteosedimentological data of a mesoscale Mediterranean catchment in S-France) and Beaulieu (2016) (glaciated catchments, northwestern USA).

With this publication, we present a comprehensive hydrometeo-sedimentological dataset for the Isábena catchment, northeastern (NE) Spain, spanning the period 2010-2018 to support the analysis and modelling of water and sediment fluxes in highly erodible mountainous Mediterranean regions. The Isábena catchment in the southern central Pyrenees is an ideal observation site, since it features very high erosion and sediment delivery rates, large temporary sediment storage and remobilization in the river system, considerable effects of partially (dis-)connected sediment fluxes and anthropogenic hydraulic alteration. The catchment shows a notable heterogeneity in terms of land use and lithology and strong orographic and pluviographic gradients.

The specificity of this dataset is the relatively long measurement period of more than 8 years (2010-2018) including several high discharge events, the comparatively large size of the catchment $\left(445 \mathrm{~km}^{2}\right)$ covered in a multi-site measurement programme and the extensive set of measured variables. The dataset consists of meteorological data (rainfall, air temperature, solar radiation, air humidity), hydrological data (river water stage, discharge) and sediment data (turbidity, suspended sediment concentration), as well as spectral reflectance data of samples of suspended sediment and soil source areas. Additionally, for two adjacent sub-catchments $\left(\sim 70 \mathrm{~km}^{2}\right)$ of the River Isábena, namely Villacarli and Carrasquero, an airborne hyperspectral image dataset, acquired in April and August 2011 with simultaneous comprehensive ground-truth data collection, as well as an airborne lidar dataset of the same area, acquired during the August 2011 campaign, are available in a separate data publication (Foerster et al., 2015).

The monitoring period comprises both comparatively wet and dry years: regarding total water yield at the catchment outlet, 2010 was the wettest year $\left(190 \mathrm{hm}^{3}\right.$, return period 4 years), while 2012 was the driest one of the monitoring period $\left(70 \mathrm{hm}^{3}\right.$, return period $\sim 18$ years) based on 70 years of observations. Concerning peak discharge, the largest flood within the monitoring period occurred on 23 November 2016 (221.15 $\mathrm{m}^{3} \mathrm{~s}^{-1}, 14$-year return period).

The comprehensive hydro-sedimentological dataset is an outcome of a long-lasting and ongoing joint research cooperation between the University of Potsdam and the German Research Centre for Geosciences (GFZ), Germany, together with the University of Lleida and the Forest Sciences Centre of Catalonia, Spain. The research was mainly conducted within the projects "SESAM: Sediment Export from large Semi-Arid Catchments: Measurement and Modelling" (2004-2008) and "Generation, transport and retention of water and suspended sediments in large dryland catchments: Monitoring and integrated modelling of fluxes and connectivity phenomena" (2010-2014), both funded by the Deutsche Forschungsgemeinschaft (DFG). The focus in the first project was on studying water yield, soil erosion, sediment transport and reservoir sedimentation, by setting up a continuous monitoring programme and developing a mesoscale process-based model. The latter project mainly focused on studying the interrelation of transfer, storage and re-entrainment, as well as connectivity processes, through a comprehensive hydro-sedimentological and spectral measurement programme at plot, hillslope and river scale and remote sensing data analysis in addition to advancing the integrated model for water and sediment fluxes to account for connectivity and scaling issues. The highly dynamic water and sediment fluxes in the Isábena catchment have been analysed in detail based on parts of the dataset published here (e.g. Francke et al., 2014; López-Tarazón et al., 2012; López-Tarazón and Batalla, 2014). Sediment connectivity for two sub-catchments of the Isábena basin was analysed based on digital elevation models obtained from airborne lidar data and surface cover fractions obtained from airborne hyperspectral imagery (Foerster et al., 2014), while sediment origins were traced back by spectral fingerprinting, based on measured spectra of suspended sediment samples and soil samples of potential sediment sources (Brosinsky et al., 2014a, b). Furthermore, for the process-based, spatially semi-distributed model WASA-SED developed for water and sediment transport in dryland catchments (Bronstert et al., 2014; Mueller et al., 2010), a framework for studying the effect of model enhancements was tested using parts of the dataset presented here (Francke et al., 2018). 

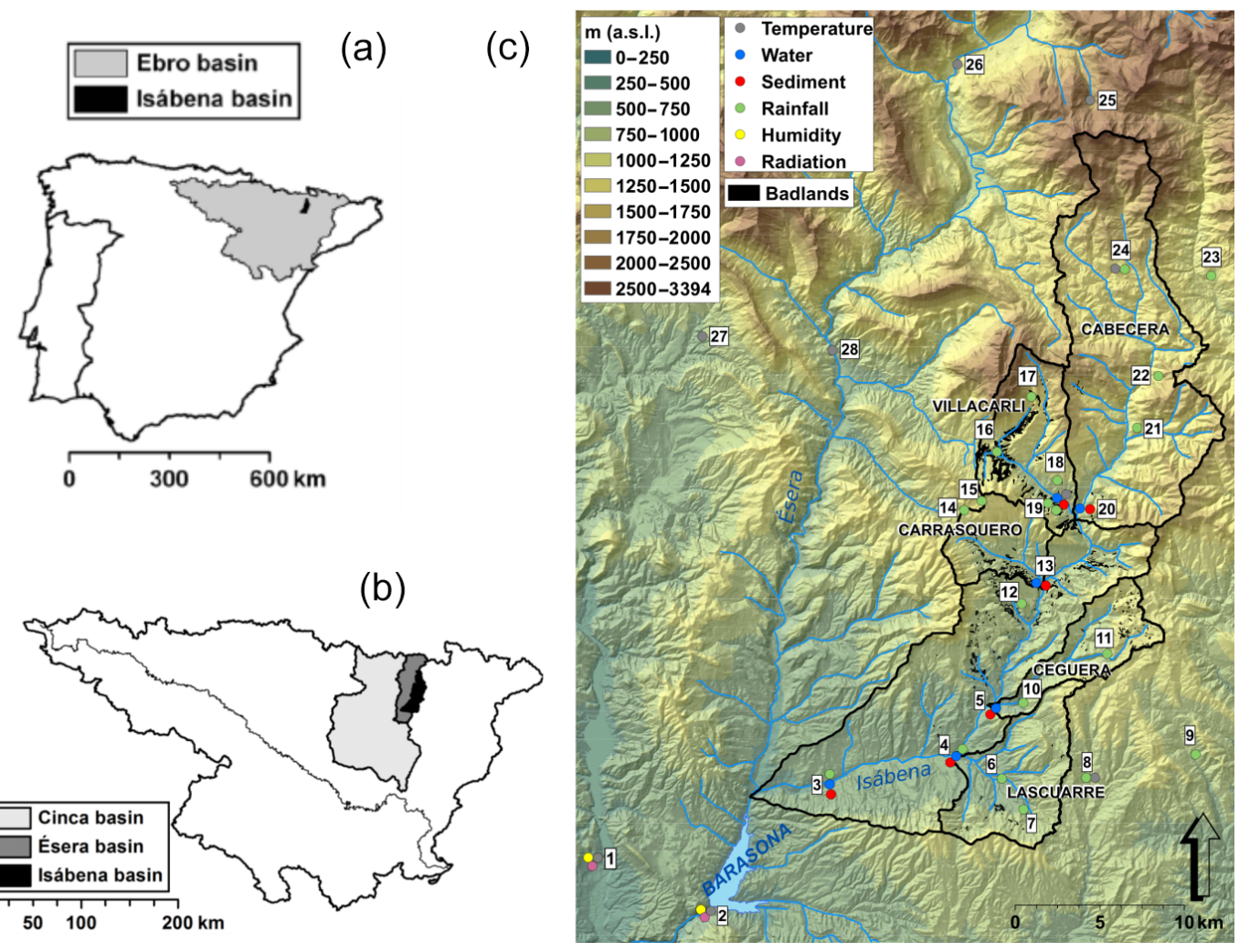

Figure 1. (a) The Isábena in the Ebro basin and in the Iberian Peninsula. (b) Location of the Isábena, the Ésera and the Cinca catchments within the Ebro River basin. (c) Digital elevation model (DEM) of the Isábena basin, in which the main sub-basins, the location of the badland areas, the Barasona Reservoir and the meteo-stations and gauging stations are shown (see Table A1 of Appendix A for station IDs).

\section{Study area}

The Isábena catchment, which drains an area of $445 \mathrm{~km}^{2}$, is located in the southern central Pyrenees (NE Iberian Peninsula) (Fig. 1). It is the main tributary of the River Ésera; both rivers are the most important tributaries of the River Cinca, in turn the second largest tributary of the Ebro (Fig. 1). The Isábena catchment is characterized by a heterogeneous relief and pronounced topography (altitude ranging from $450 \mathrm{~m}$ to $2720 \mathrm{~m}$ a.s.1.), leading to marked temperature and precipitation gradients (Verdú et al., 2006). The catchment has a wet and cold continental Mediterranean climate, with both Atlantic and Mediterranean influences (García-Ruiz et al., 2001). Mean annual precipitation ranges from $450 \mathrm{~mm}$ in the lowlands to $1600 \mathrm{~mm}$ in the upland areas, with a total mean annual precipitation of $770 \mathrm{~mm}$ (CHEBRO, 2012).

Flow regimes in the River Isábena are characterized by a pluvial regime, with contributions from snowmelt from the upper parts of the catchment. Floods typically occur in spring, triggered by frontal precipitation events, sometimes in combination with snowmelt, and in late summer and autumn caused by localized thunderstorms. The mean discharge estimated at the outlet of the basin (Capella gauging station, EA047; Fig. 1) is $4.1 \mathrm{~m}^{3} \mathrm{~s}^{-1}$, but maximum dis- charges of up to $370 \mathrm{~m}^{3} \mathrm{~s}^{-1}$ have been observed (August 1963, return period of 94 years calculated by the Gumbel method from a series of annual maximum instantaneous discharges for the period 1945-2015); minimum discharges are below $1 \mathrm{~m}^{3} \mathrm{~s}^{-1}$, but the river never dries up. The mean annual water yield is $177 \mathrm{hm}^{3}$, a value that represents $\sim 1.5 \%$ of the total runoff in the whole Ebro River basin (López-Tarazón et al., 2009).

The catchment is not hydraulically regulated; thus its hydrological regime is determined by natural factors only. However, the Isábena drains into the Barasona Reservoir, which is responsible (together with the Ésera) for its severe siltation due to the large amounts of suspended sediments which both rivers deliver. Instantaneous suspended sediment concentrations of up to $350 \mathrm{~g} \mathrm{~L}^{-1}$ have been measured at the basin outlet (López-Tarazón et al., 2009), generating mean suspended sediment loads above $250000 \mathrm{t} \mathrm{yr}^{-1}$ (i.e. period 2005-2010; López-Tarazón and Batalla, 2014), which correspond to a specific yield of about $600 \mathrm{t} \mathrm{km}^{2} \mathrm{yr}^{-1}$. This can be considered high to very high in comparison with catchments of the same size in this and other regions (Francke et al., 2014; López-Tarazón et al., 2012; de Vente et al., 2006) Sediments mainly originate from the central part of the catchment (Fig. 1), in a corridor of Eocene marls with sandstones. 
Table 1. Summary of data contained in the dataset.

\begin{tabular}{|c|c|c|c|c|}
\hline Variable & $\begin{array}{l}\text { No. of } \\
\text { stations/ } \\
\text { sites }\end{array}$ & Instrument/source & $\begin{array}{l}\text { Resolution } \\
(\mathrm{min})\end{array}$ & $\begin{array}{l}\text { Variable Code } \\
\text { in database }\end{array}$ \\
\hline Precipitation & $6^{1}+12$ & tipping bucket & breakpoint, 1,15 & rainfall_* \\
\hline Air temperature & $8^{1}+1$ & \multirow{3}{*}{ 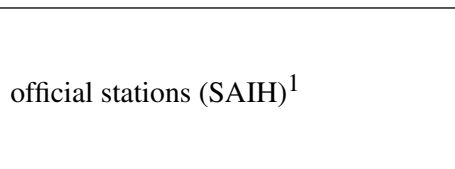 } & \multirow{3}{*}{15} & temperature \\
\hline Solar radiation ${ }^{1}$ & 2 & & & global_radiation \\
\hline Air humidity 1 & 2 & & & relative_humidity \\
\hline Water stage & $1^{1}+5$ & capacitive, microwave, shaft encoder & $1,5,15$ & water_stage_* \\
\hline \multirow[t]{2}{*}{ Discharge } & \multirow[t]{2}{*}{$1^{1}+5$} & dilution, current meters & sporadic & \multirow{2}{*}{ discharge_metering, discharge_* } \\
\hline & & from water stage & $1,5,15$ & \\
\hline Turbidity & 3 & turbidimeters & $1,5,15$ & turbidity_$^{*}$ \\
\hline \multirow{2}{*}{$\begin{array}{l}\text { Suspended sediment } \\
\text { concentration }\end{array}$} & 5 & manual and automatic samplers & sporadic, event-based & \multirow{2}{*}{$\begin{array}{l}\text { ssc_generic, ssc_ISCO, ssc_manual, } \\
\text { ssc_continuous_* }\end{array}$} \\
\hline & 3 & from turbidity & $1,5,15$ & \\
\hline $\begin{array}{l}\text { Reflectance spectra of } \\
\text { soil samples }\end{array}$ & 152 & \multirow{2}{*}{$\begin{array}{l}\text { in situ and laboratory } \\
\text { spectroscopy }\end{array}$} & - & _wavelength_nm_350-2151 \\
\hline $\begin{array}{l}\text { Reflectance spectra of } \\
\text { sediment samples }\end{array}$ & 351 & & - & _wavelength_nm_350-2151 \\
\hline
\end{tabular}

* denotes further suffixes in the names indicating the respective resolution, e.g. "rainfall_15".

${ }^{1}$ Data from operational data service (SAIH).

The marls are exposed to the surface in badland structures (bare surfaces on highly erodible sediments). Badlands are the main sediment sources of the catchment (López-Tarazón et al., 2009) despite their small area (less than $1 \%$ of the Isábena catchment area).

\section{Methods}

Water and sediment fluxes have been monitored in the Isábena catchment in the context of hydro-sedimentological research since 2004. Additionally, the Ebro Water Authorities (CHE) maintain a network of monitoring stations for precipitation, temperature, radiation and discharge for operational purposes (Sistema Automático de Información Hidrológica, Automatic System of Hydrological Information, SAIH) of which some of the data are included in the presented dataset. Besides these hydro-meteorological time series, the dataset also contains data on spectral properties of soil and sediment samples from terrestrial and riverine parts of the catchment (see Table 1 for an overview). The details of the dataset (measurement techniques, data processing and checking) are given in the following sections. All data are provided according to the CUAHSI HIS standard, which is explained in Sect. 4. Table 1 provides an overview of the content of the database. Details on the instrumentation for each single location can be found in the respective CUAHSI table "Methods", and a complete list of measured variables is con- tained in the CUAHSI table "Variables". Figure 2 illustrates the data coverage of the time series.

Other data acquired during the research activities are not part of this publication. They include multiple sets of space and airborne imagery, terrestrial laser scans of river sections and of badland sites, water and sediment time series of three gauging stations upstream of gauge Villacarli and data on particle movement and soil moisture in a badland site. These data can be requested from the authors, if processing has been finished and licensing permits it.

\subsection{Meteorological data}

Within the project context, rainfall was the only meteorological variable monitored at 12 stations (Sect. 3.1.1). However, other meteorological variables (e.g. temperature, radiation) were measured and operationally collected by the SAIH network (Sect. 3.1.2).

\subsubsection{Rainfall}

A total of 12 rain gauges were installed and distributed across the catchment and its vicinity to complement the official coverage of the rainfall network (12 official rain gauges are located within and/or close to the Isábena catchment) (Fig. 1). Two different types of rain gauges were installed: (1) a tipping bucket precipitation transmitter 5.4032.XXX (Thies Clima, Göttingen, Germany), connected to a data log- 
ger CR-1000 (Campbell Scientific Ltd., Shepshed, England), installed in Villacarli and in Lascuarre outlets (Fig. 1), and (2) a Davis rain gauge connected to a Hobo Event data logger, installed in the rest of the project rainfall stations. The rain gauges have been calibrated in situ with dripping bottles repeatedly after their set-up. As these calibrations did not differ notably, an invariant calibration was used for the entire time period. In the case of the official precipitation stations (Fig. 1) all the installed rain gauges were different models of tipping bucket transmitters (Thies Clima, Göttingen, Germany).

All rainfall data have been checked and periods of malfunctioning (i.e. clogged funnels) have been removed by comparing plots of cumulative rainfall sums of adjacent stations. Recent analysis by Rottler et al. (2018) indicated that snow accumulation in the tipping buckets is generally negligible.

\subsubsection{Air temperature, air humidity and solar radiation}

These meteorological variables have been courteously provided by the Ebro Water Authorities. They are operationally monitored within the SAIH network. Thus, we limited the post-processing to the removal of periods of implausible data and visual checks. While we chose not to alter the data, some observations may be of interest to the potential user: global radiation time series show a slight but steady decrease in recorded values over time: for El Grado, this recession seems to end in spring 2017 (which could be due to sensor cleaning or renewal). At the Barasona station, maximum recorded values of relative air humidity decrease slightly but steady over time. At El Grado (5 km west of Barasona Reservoir), recorded values of relative air humidity jump to higher values in 2012. In both time series of relative air humidity, values never reach $100 \%$.

\subsection{Hydrological data}

Streamflow was monitored at the outlet of the catchment and of five sub-catchments (see Figs. 1 and 3) by continuously measuring the water stage (Sect. 3.2.1). Occasional discharge metering (Sect. 3.2.2) allowed the rating curves to be defined for the conversion of the water stage into time series of discharge (Sect. 3.2.3).

\subsubsection{Water stage}

The water stage was monitored at the outlet of the catchment and of five sub-catchments (Figs. 1,3). Capella is the official gauging station of the Isábena catchment. Its broad-crested weir forms an artificial cross section and is equipped with a shaft encoder for water stage measurements, recorded every $15 \mathrm{~min}$. For the sub-catchments, water levels were measured at cross sections close to the sub-basin outlets, where access and conditions in terms of comparatively well defined
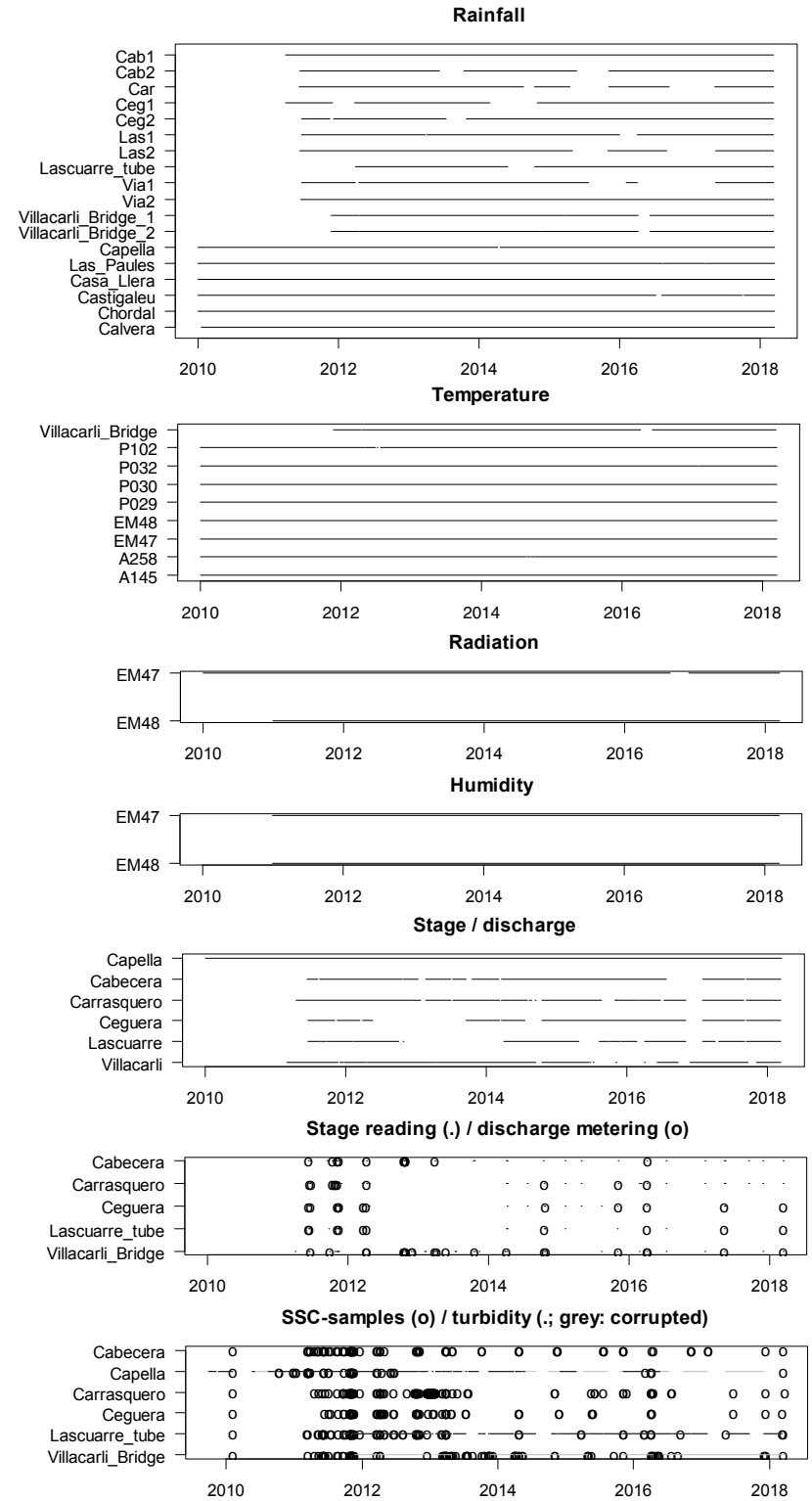

Figure 2. Data coverage of time series. The symbols (line/dot, circle) demark that data for the respective day are available.

and stable cross sections were favourable (i.e. bridges). Table 2 summarizes the specifications of each gauging station. At Villacarli, a microwave stage recorder (RQ 24; Sommer $\mathrm{GmbH}$, Koblach, Austria) was used to measure water level and flow velocity at a high temporal resolution of $1 \mathrm{~min}$. At all other stations, capacitive water stage loggers (WT-HR; TruTrack Ltd., Christchurch, New Zealand) with a temporal resolution of $5 \mathrm{~min}$ were used. Manual readings were performed regularly to verify and complement the automatic data. The water stage records were calibrated against these readings at a fixed gauge datum to account for sensor drift.

For gauges Carrasquero, Ceguera and Villacarli (see Fig. 1), changes in the geometry of the streambed were ob- 


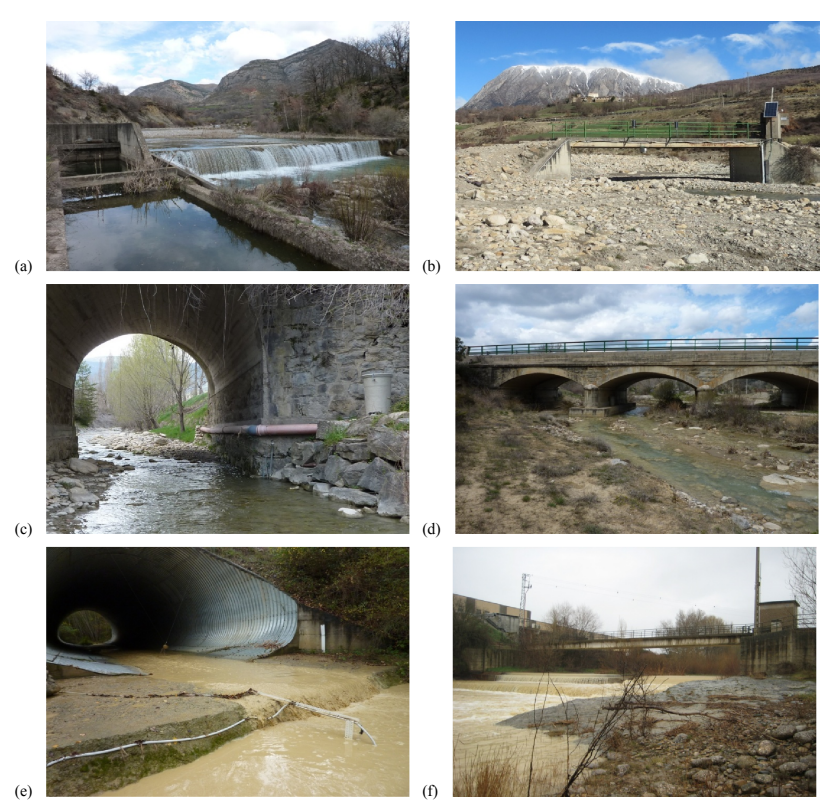

Figure 3. View of stream gauging stations (a: Cabecera, b: Villacarli, c: Carrasquero, d: Ceguera, e: Lascuarre, f: Capella).

served after heavy floods. The times of these changes have been reconstructed manually; the respective difference to the effective flow level has been added as offset information in the database. Thus, both the absolute water level $h_{\mathrm{abs}}$ and the effective water level $h_{\text {eff }}$ can be retrieved with

$h_{\text {eff }}=h_{\text {abs }}-$ offset.

For the subsequent steps, $h_{\text {eff }}$ was used.

Gauge Capella was occasionally affected by the partial siltation of the stilling well, resulting in the float being stuck above the actual water level, until the next maintenance was done. The affected low flow periods have been identified and tagged as "less than" in the CUAHSI table.

\subsubsection{Discharge metering}

At all stream gauges, repeated manual discharge meterings with the velocity-area method or the dilution method were conducted to establish and extend the gauge-specific water stage-discharge relationships (rating curves) (Table 2). One of the two methods was chosen according to the actual site and flow conditions at the time of the measurement. At low flow conditions and when the stream cross section was not inaccessible due to too high flow, the salt dilution method was used with tracer equipment (TQ-Tracer, Sommer GmbH, Koblach, Austria) or conductance meters (Cond 3310; WTW $\mathrm{GmbH}$, Weilheim Germany). During all other conditions, current meters (C2; Ott GmbH, Kempten, Germany) and acoustic devices (Ott-ADC; Ott GmbH, Kempten, Germany; FlowTracker, SonTek, San Diego, USA) were used. The respective metering data are included in the database. Associ- ated measurement uncertainties were estimated based on recommendations from multiple sources (Le Coz et al., 2014; Pelletier, 1988; Westerberg et al., 2011; see the Supplement for details).

\subsubsection{Discharge time series}

Table 2 lists the number of discharge meterings available for each river gauge. For the catchment outlet, water level is converted into discharge by means of the water stage-discharge rating curve developed by the authors (for more information, see López-Tarazón et al., 2010), which included the effect of the high suspended sediment concentrations that usually flow through the cross section (hence likely decreasing turbulence, thus providing a higher discharge at the same water level in comparison to clean water). For the sub-catchments, these meterings were used to construct rating curves using Bayesian curve fitting (BaratinAGE, version 2.1, Le Coz et al., 2014) and to derive the time series of discharge from the water stage series (see Sect. 3.2.1). This procedure additionally yielded the associated $95 \%$ confidence interval CI (for water stage and the parametric uncertainty). As the CUAHSI standard only supports the recording of symmetrical uncertainty measures, CI was approximated as symmetrical and included in the data table in the CUAHSI field "ValueAccuracy" as $0.5^{*} \mathrm{CI}$.

For the gauges with correction of the zero flow level (see Sect. 3.2.1), this implies the assumption that the remaining hydraulic controls (lateral restrictions by bridge walls, bed roughness and slope) remained unaltered, which seems a reasonable assumption according to observations. Still, the resulting uncertainty in discharge contained in the database will probably be optimistic.

In spite of great efforts to also cover high flow conditions with measurements, the very highest water stages could not be accompanied by discharge meterings. At these high stages, we expect no change of hydraulic control for the weirshaped cross sections (Capella, Cabecera), the confinements of the bridge walls (Ceguera, Carrasquero, Villacarli) nor the pipe of corrugated metal (Lascuarre), allowing the extrapolation of the rating curve.

As some of the instruments yielded a "stepped" time series of stage, the resulting discharge time series were stepcorrected using the RHydro package (Reusser et al., 2012), which removed plateaux by interpolating the respective adjacent non-plateaux values.

\subsection{Suspended sediment concentration}

\subsubsection{Water samples}

At all stream gauges, water samples were taken manually and automatically with automatic samplers (ISCO 3700) on an event-based scheme. These samples were then filtered or decanted for higher concentrations. The resulting sediment was oven-dried and weighted ( $\left.m_{\text {Sed }}, \mathrm{g}\right)$, to allow the computation 
Table 2. Summary of stream gauge properties.

\begin{tabular}{lrllrr}
\hline Gauge & $\begin{array}{r}\text { Drainage area } \\
\left(\mathrm{km}^{2}\right)\end{array}$ & Setting & $\begin{array}{l}\text { Stage } \\
\text { recording }\end{array}$ & $\begin{array}{r}\text { Resolution } \\
(\mathrm{min})\end{array}$ & $\begin{array}{r}\text { Number of } \\
\text { meterings }\end{array}$ \\
\hline Cabecera & 146 & broad-crested weir & capacitive $^{\mathrm{a}}$ & 5 & 18 \\
Capella & 445 & broad-crested weir & shaft encoder & 15 & 6 \\
Carrasquero & 25 & gravel-bed below bridge & capacitive $^{\mathrm{a}}$ & 5 & 10 \\
Ceguera & 28 & gravel-bed below bridge & capacitive $^{\mathrm{a}}$ & 5 & 12 \\
Lascuarre & 45 & corrugated metal pipe & capacitive $^{\mathrm{a}}$ & 5 & 10 \\
Villacarli & 42 & gravel-bed below bridge & microwave $^{\mathrm{b}}$ & 1 & 32 \\
\hline
\end{tabular}

a WT-HR; TruTrack Ltd. ${ }^{\text {b }}$ RQ-24; Sommer GmbH.

of the initial suspended sediment concentration (SSC; $\mathrm{gL}^{-1}$ ) as

$\mathrm{SSC}=m_{\text {Sed }} / V_{\text {Water }}$,

where $V_{\text {Water }}$ is the volume of water abstracted from the sample (L). The respective SSC data are part of the database.

The representativity of side samples in relation to the mean SSC at the section can generally be assumed to be acceptable due to the observed high flow turbulence and the predominantly fine sediment fractions. Thus, both manually and automatically taken samples are considered equally representative.

\subsubsection{Turbidity measurements and continuous SSCs}

At the gauges Villacarli, Lascuarre and Capella, turbidimeters recorded turbidity in 5,5 and $15 \mathrm{~min}$ (from averages of $5 \mathrm{~s}$ instrument readings), respectively. The installed turbidimeters are Turbimax WCUS41 Endress+Hauser AG, Reinach, CH (Capella, until November 2015) and WTW ViSolid (all other periods). The turbidimeters are then connected to Campbell CR-510/CR-1000 (Campbell Scientific Inc., Logan, Utah, USA) or MIQ (WTW) data loggers which record and store the raw turbidity values. The database contains these raw data of the sensors (in $\mathrm{mA}, \mathrm{g} \mathrm{SiO}_{2}$ and turbidity units, respectively).

Despite the auto-cleaning feature of the sensors, the sensor signal showed more (Villacarli) or less (Lascuarre, Capella) pronounced deterioration over time, namely by an increasing zero level with occasional sudden drops. This offset has been corrected manually and stored along in the database (turbidity $_{\text {eff }}=$ turbitidy $_{\text {raw }}-$ offset). For some periods, the sensor signal appeared completely corrupted (e.g. due to sensor burial, extreme low flow). These periods have been preserved to allow the analysis of this behaviour. They have been tagged in the database via the QualityControlLevelCode field as erroneous and are excluded from further processing (i.e. conversion to SSCs).

Using the above-mentioned lab samples, the valid turbidimeter data were converted to SSCs using quadratic regression, constituting separate time series in the database.
These rating curves are considered invariant for the time period (for plot, see the Supplement).

\subsection{Spectral data}

Spectral analyses were carried out for soil and sediment samples taken from the study area. This comprises 351 sediment samples from the river collected during flood events (see Sect. 3.3.1) and 152 soil samples from the main potential sediment source areas within the Isábena catchment (see Fig. 1 in Brosinsky et al., 2014a). Details on sampling and spectral measurement procedures can be found in the subsequent sections. Further details on the spatial location of sampling sites as well as the use of these data in (spectral) fingerprinting studies to trace back the origin of suspended sediments are given in Brosinsky et al. (2014a, b).

\subsubsection{Spectra of soil samples from source areas}

Source area soil samples were collected during two field campaigns in October 2010 and June 2011. Sampling sites were selected based on previous analyses of land use distribution (MARM, 2008), erosion susceptibility (Fargas et al., 1997) and accessibility. This sampling included all major land use types, namely forest (covering $47 \%$ of the catchment area), shrubland (30\%), agricultural land (14\%) and grassland $(8 \%)$. In addition, potential source areas that cover only small parts of the river basin $(<1 \%)$ but that were suspected to contribute high proportions of suspended sediment were sampled, including badlands, unpaved roads and open slopes exposing soil next to roads or channels. Sampling sites were chosen in close vicinity $(<100 \mathrm{~m})$ to stream or river reaches to ensure the connectivity of potential sources to the river network. At each site, five grab samples of easily erodible material (top $1-3 \mathrm{~cm}$ ) were collected from a representative area of approximately $5 \mathrm{~m} \times 5 \mathrm{~m}$ in size.

Spectral reflectance was measured as the ratio of reflected radiation to the total radiation incident on a surface as a function of wavelength (Baumgardner et al., 1985), both (1) in situ during material collection, and (2) in the laboratory following some pre-processing of the samples. In both cases, an ASD FieldSpec3 Hi-Res portable spectroradiometer (An- 
alytical Spectral Device Inc., Boulder, USA) was deployed, using a white reference (95\% Zenith Alucore Reflectance Target, SphereOptics GmbH, Uhldingen, Germany) as standard. The ASD spectroradiometer acquires 2151 channels in the $0.35-2.5 \mu \mathrm{m}$ spectral range at a true sampling interval of $1.4 \mathrm{~nm}$ in the visible and near-infrared (VNIR) region $(0.35-$ $1.0 \mu \mathrm{m})$ and $2 \mathrm{~nm}$ in the shortwave infrared (SWIR) region $(1.0-2.5 \mu \mathrm{m})$.

In situ reflectance spectra were collected just before grab sampling at the corresponding location with an accessory light source (contact probe) mounted on the light-collecting head of the ASD spectroradiometer. This keeps illumination conditions stable and excludes atmospheric influences for all measurements.

For laboratory measurements, the source material collected from the five locations per site was thoroughly mixed to provide homogeneous samples, dry sieved to $63 \mu \mathrm{m}$ to minimize differences in particle size composition between source and sediment material (e.g. Peart and Walling, 1986; Smith and Blake, 2014), placed in shallow $5 \mathrm{~cm} \times 5 \mathrm{~cm}$ plastic containers and oven-dried at $60^{\circ} \mathrm{C}$ for $24 \mathrm{~h}$ prior to spectral measurements. Then, spectral readings were taken in a dark room facility using the same ASD spectroradiometer and white reference as in the field. Illumination was provided by a $2000 \mathrm{~W}$ lamp installed at approximately $80 \mathrm{~cm}$ from the sample at a zenith angle of $45^{\circ}$, and the optical head of the ASD was mounted perpendicular to the sample. For each sample, four readings were taken and subsequently averaged, with the sample rotated $90^{\circ}$ after every reading to reduce illumination effects. For more details see Brosinsky et al. (2014a).

\subsubsection{Spectra of suspended sediment samples}

The sampling of suspended sediment material by means of automatic ISCO samplers is described in Sect. 3.3.1. All spectral reflectance measurements of suspended sediment material were taken in the laboratory similar to those of source material (see Sect. 3.4.1).

Four events sampled at the catchment outlet (Capella gauging station) were chosen for spectral analysis, namely the events of (a) 24/25 September 2011, (b) 22 March 2012, (c) 3/4 June 2012 and (d) 20 June 2012. For that purpose, the material was gently disaggregated using pestle and mortar, if necessary, and further processed and measured similar to the source area material in the laboratory (Sect. 3.4.1).

In addition to material from Capella, suspended sediment collected at the five sub-catchment outlets was prepared for analyses. However, the SSC at some sub-catchment outlets was often substantially lower and thus the amount of collected material was insufficient for spectral laboratory measurements as described above for which $>2 \mathrm{~g}$ are required. Therefore, these samples were either measured using the sediment layer on the glass fibre filters that remained from SSC analyses, or from glass fibre filters specifically pre- pared for the spectral measurements. Again, spectral measurements followed the laboratory protocol described above. Since we detected spectral differences between loose material and material on filters that are most likely caused by the alignment of sediment particles during vacuum filtration, the measurements should not be compared directly (Brosinsky et al., 2014a).

For each sample (in situ, loose source material, loose sediment material and sediment on filters in the lab, respectively), mean reflectance spectra were calculated and detector jumps at 1.0 and $1.83 \mu \mathrm{m}$ occurring on rare occasions were corrected by adaptation to the first detector. All spectra were then smoothed using a Savitzky-Golay filter (Savitzky and Golay, 1964), with a kernel size of 7.

\section{Data availability}

To maximize the ease of reusability of the data, we have created a database following the CUAHSI HIS standard proposed by the Consortium of Universities for the Advancement of Hydrologic Science (Couch et al., 2014; Horsburgh et al., 2008).

This standard defines a structure of a relational database, which allows the unequivocal storage of measured values and the associated metadata. Besides being listed in a central directory (HIS Central Catalog) for improved visibility, the dataset can be explored using a variety of stand-alone tools, APIs or packages to access the data, i.e. HydroDesktop (Ames et al., 2012), HydroClient, or the WaterML R package (Kadlec et al., 2015).

The database can be found in the HISCENTRAL catalogue (http://hiscentral.cuahsi.org/pub_network.aspx?n= 5622, last access: 11 June 2018). It is directly accessible via the API (http://hydroportal.cuahsi.org/isabena/cuahsi_1_ 1.asmx?WSDL, last access: 11 June 2018). The necessary infrastructure was courteously provided by the CUAHSI Water Data Center. The dataset is published through GFZ Data Services (Francke et al., 2018; http://doi.org/10.5880/fidgeo. 2018.011, last access: 11 June 2018), which provides the raw text files in CUAHSI HIS standard. Additional to the time series, this repository contains supplementary materials (BaRatin input files, rating curves) and template scripts for data retrieval, processing and visualization.

\section{Conclusions}

We present an extensive dataset of meteorological, hydrological and sediment data including time series, individual meterings and spectral reflectance data from multiple monitoring and sampling points throughout the mesoscale Isábena basin. All time series data consistently cover a monitoring period of 8 years (2010-2018), comprising years and seasons with markedly different mean meteorological conditions and several major flood events. 
Where applicable, the dataset contains time series in the highest recorded temporal resolution (e.g. breakpoint data for rainfall). Furthermore, for relevant variables (i.e. stage, turbidity) both raw and corrected data are provided. This allows specific aspects of these variables to be analysed or limitations of the recording instruments to be assessed (e.g. shortterm rainfall intensities, discharge in moving-bed rivers).

As a whole, the dataset allows discharge dynamics to be studied in different parts of the catchment and its response to the spatio-temporal characteristics of the driving rainfall fields. It enables sediment fluxes from the highly erosive upland parts of the catchment, the badland areas in particular, along the river network to be linked to the catchment outlet, where severe siltation affects the downstream Barasona Reservoir, and the suspended sediment collected at the outlets of (sub-)catchments to be traced back to its source areas. Overall, the data support an advanced understanding of water and sediment fluxes and budgets and related sediment connectivity processes and phenomena in mountainous Mediterranean catchments. In its high spatial and temporal resolution and comprehensiveness, the dataset is expected to serve as a highly valuable benchmark for evaluating, calibrating and further developing hydro-sedimentological catchment models. It has further potential to aid the design of long-term sediment management programmes in highly active geomorphic regions with an important role in water resource sustainability, such as the Isábena. 


\section{Appendix A}

The digital annex contains the scripts used in the processing of the data. It also provides detailed comments on single steps of the data processing.

Table A1. Monitoring stations depicted in Fig. 1.

\begin{tabular}{llll}
\hline ID & Station & ID & Station \\
\hline 1 & El Grado & 15 & Chordal \\
2 & Barasona & 16 & Via1 \\
3 & Capella & 17 & Via2 \\
4 & Lascuarre_tube, Las3 & 18 & Villacarli \\
5 & Ceguera & 19 & Villacarli Bridge_* \\
6 & Las1 & 20 & Cabecera \\
7 & Las2 & 21 & Cab1 \\
8 & Castigaleu & 22 & Calvera \\
9 & CasaLlera & 23 & Cab2 \\
10 & Ceg1 & 24 & Las Paules \\
11 & Ceg2 & 25 & Cerler \\
12 & Roda & 26 & Eriste \\
13 & Carrasquero & 27 & Samper \\
14 & Car & 28 & Campo \\
\hline
\end{tabular}

Table A2. Additional data sources providing data for potential model parameterizations.

\begin{tabular}{lllll}
\hline Dataset & Source & Resolution & Provider/institution & Link \\
\hline DEM & $\begin{array}{l}\text { DEM generated } \\
\text { from ASTER } \\
\text { and SRTM data } \\
\text { using stereo- } \\
\text { correlation }\end{array}$ & $15 \mathrm{~m}$ & $\begin{array}{l}\text { German Aerospace } \\
\text { Center (DLR) }\end{array}$ & $\begin{array}{l}\text { http://eoweb.dlr.de:8080/index.html } \\
\text { (last access: 11 June 2018) }\end{array}$ \\
\hline $\begin{array}{l}\text { Soil map } \\
\text { and } \\
\text { properties }\end{array}$ & $\begin{array}{l}\text { European Soil } \\
\text { Database derived } \\
\text { data } \\
\text { (Hiederer, 2013) }\end{array}$ & $1 \mathrm{~km}$ & $\begin{array}{l}\text { European Soil } \\
\text { Database derived } \\
\text { data } \\
\text { (Hiederer, 2013) }\end{array}$ & $\begin{array}{l}\text { http://eusoils.jrc.ec.europa.eu/ESDB_Archive/ESDBv2/index.htm } \\
\text { (last access: 11 June 2018) }\end{array}$ \\
\hline Lithology & $\begin{array}{l}\text { CHEBRO } \\
\text { (CHEBRO, 1993) }\end{array}$ & $1: 50000 /$ & CHEBRO & $\begin{array}{l}\text { http://iber.chebro.es/geoportal/ } \\
\text { (last access: 11 June 2018) }\end{array}$ \\
\hline $\begin{array}{l}\text { Plant } \\
\text { parameters }\end{array}$ & $\begin{array}{l}\text { PlaPaDa } \\
\text { (Breuer et al., 2003) }\end{array}$ & & $\begin{array}{l}\text { PlaPaDa - an online } \\
\text { plant parameter data } \\
\text { drill for eco-hydrological } \\
\text { modelling approaches. }\end{array}$ & $\begin{array}{l}\text { http://www.staff.uni-giessen.de/ gh1461/plapada/plapada.html } \\
\text { (last access: 11 June 2018) }\end{array}$ \\
\hline Land use & $\begin{array}{l}\text { CHEBRO } \\
\text { (CHEBRO, 1998) }\end{array}$ & $1: 100000$ & CHEBRO & $\begin{array}{l}\text { http://iber.chebro.es/geoportal/ } \\
\text { (last access: 11 June 2018) }\end{array}$ \\
\hline
\end{tabular}


Table A3. Overview of studies that have so far used (parts of) the dataset described in this publication.

\begin{tabular}{lll}
\hline Authors, year of publication & Objective & Type of data used \\
\hline López-Tarazón et al. (2012) & Quantify the sediment budget of the Isábena basin & $\begin{array}{l}\text { Meteorological data, hydrological data, } \\
\text { suspended sediment concentration }\end{array}$ \\
\hline Brosinsky et al. (2014a) & $\begin{array}{l}\text { Trace back sediment origin by spectral } \\
\text { fingerprinting: application to flood } \\
\text { events in Isábena basin }\end{array}$ & $\begin{array}{l}\text { Meteorological data, hydrological data, } \\
\text { suspended sediment concentration, } \\
\text { spectral data }\end{array}$ \\
\hline Brosinsky et al. (2014b) & $\begin{array}{l}\text { Trace back sediment origin by spectral } \\
\text { fingerprinting: method development }\end{array}$ & Spectral data \\
\hline Foerster et al. (2014) & $\begin{array}{l}\text { Assess sediment connectivity from vegetation } \\
\text { cover and topography in two sub-basins } \\
\text { of the Isábena basin }\end{array}$ & $\begin{array}{l}\text { Airborne lidar and hyperspectral data as } \\
\text { well as in situ ground cover data made } \\
\text { available in Foerster et al. (2015) }\end{array}$ \\
\hline Francke et al. (2014) & $\begin{array}{l}\text { Analyse runoff, sediment dynamics and } \\
\text { sediment yield of sub-catchments in } \\
\text { in the Isábena basin }\end{array}$ & $\begin{array}{l}\text { Meteorological data, hydrological data, } \\
\text { suspended sediment concentration }\end{array}$ \\
\hline $\begin{array}{l}\text { López-Tarazón } \\
\text { and Batalla (2014) }\end{array}$ & $\begin{array}{l}\text { Assess dominant discharges and associated } \\
\text { sediment dynamics of the River Isábena }\end{array}$ & $\begin{array}{l}\text { Hydrological data, suspended } \\
\text { sediment concentration }\end{array}$ \\
\hline Francke et al. (2018) & $\begin{array}{l}\text { Propose framework to assess the effect of model } \\
\text { enhancements shown in the example of the WASA-SED } \\
\text { model applied to the Isábena basin }\end{array}$ & $\begin{array}{l}\text { Meteorological data, hydrological data, } \\
\text { suspended sediment concentration }\end{array}$ \\
\hline
\end{tabular}


Author contributions. TF initiated the drafting of the paper, designed and implemented parts of the monitoring programme, supervised or conducted the revision of meteo, discharge and sediment flux data and coordinated the generation of the database.

JALT mediated data flow with SAIH and attended to the Capella gauge and its data.

$\mathrm{AB}$ and SF conducted all sampling, processing and analyses of the spectral data.

ES contributed large parts of the station maintenance, specifically at gauge Villacarli.

AG contributed in developing the monitoring design and installation of monitoring stations.

All of the above-mentioned scientists actively participated in the fieldwork campaigns and contributed sections of the paper.

$\mathrm{RB}, \mathrm{AG}, \mathrm{SF}$ and $\mathrm{AB}$ acquired project funds, supervised the project and revised the final version of the manuscript.

Competing interests. The authors declare that they have no conflict of interest.

Acknowledgements. The collection and processing of the data presented in this paper were mainly funded within two research projects by the Deutsche Forschungsgemeinschaft (DFG): SESAM ("Sediment Export from Large Semi-Arid Catchments: Measurements and Modelling", 2004-2009, BR 1731/3) and WASESAC ("Generation, transport and retention of water and suspended sediments in large dryland catchments: Monitoring and integrated modelling of fluxes and connectivity phenomena", 2010-2015, BR 1731/4-1-2). Data collection beyond the project time frame was financially supported by the Helmholtz Centre for Environmental Research (UFZ).

José Andrés López-Tarazón is in receipt of a Marie Curie Intra-European Fellowship (FLOODHAZARDS Project, PIEF-GA2013-622468; 7th EU Framework Programme). José Andrés LópezTarazón and Ramon J. Batalla acknowledge the support from the Economy and Knowledge Department of the Catalan Government through the Consolidated Research Group 2014 SGR 645 (RIUSFluvial Dynamics Research Group).

Special thanks are due to the Ebro Water Authorities and its "Sistema Automático de Información Hidrológica y de Comunicación Fónica" (SAIH) for their permission to install the measuring equipment at the Capella gauging station, for collaborative support during the investigation and for providing field assistance and many useful data. In addition, the authors gratefully acknowledge the local communities and land owners for property access, cooperation and the permission to install observation systems.

For their efforts and commitment, we want to thank the numerous students, interns and student assistants who were involved in field and lab work. Within the project, several Bachelor and Master's theses were realized; especially the work of Charlotte Wilczok contributed directly to the understanding and improvement of the presented dataset. We warmly thank all our colleagues from the Universities of Lleida and Potsdam, the German Research Centre for Geosciences (GFZ) and the Forest Technology Centre of Catalonia, including former project members and technicians, who helped in designing, installing and maintaining the monitoring systems and field stations.
Edited by: Kirsten Elger

Reviewed by: two anonymous referees

\section{References}

Ames, D. P., Horsburgh, J. S., Cao, Y., Kadlec, J., Whiteaker, T., and Valentine, D.: HydroDesktop: Web services-based software for hydrologic data discovery, download, visualization, and analysis, Environ. Modell. Softw., 37, 146-156, https://doi.org/10.1016/j.envsoft.2012.03.013, 2012.

Baumgardner, M. F., Silva, L. F., Biehl, L. L., and Stoner, E. R.: Reflectance Properties of Soils, Adv. Agron., 38, 1-44, https://doi.org/10.1016/S0065-2113(08)60672-0, 1985.

Beaulieu, J.: Turbidity and Sediment Monitoring, HydroShare, available at: https://www.hydroshare.org/resource/ 99a170544d2741ac983a1f25b2f38451/ (last access: 7 June 2017), 2016.

Bronstert, A., de Araújo, J.-C., Batalla, R. J., Costa, A. C., Delgado, J. M., Francke, T., Foerster, S., Guentner, A., López-Tarazón, J. A., Mamede, G. L., Medeiros, P. H., Mueller, E., and Vericat, D.: Process-based modelling of erosion, sediment transport and reservoir siltation in mesoscale semi-arid catchments, J. Soils Sediments, 14, 2001-2018, https://doi.org/10.1007/s11368-0140994-1, 2014.

Brosinsky, A., Foerster, S., Segl, K., López-Tarazón, J. A., Piqué, G., and Bronstert, A.: Spectral fingerprinting: characterizing suspended sediment sources by the use of VNIRSWIR spectral information, J. Soils Sediments, 14, 1965-1981, https://doi.org/10.1007/s11368-014-0927-z, 2014a.

Brosinsky, A., Foerster, S., Segl, K. ,and Kaufmann, H.: Spectral fingerprinting: sediment source discrimination and contribution modelling of artificial mixtures based on VNIRSWIR spectral properties, J. Soils Sediments, 14, 1949-1964, https://doi.org/10.1007/s11368-014-0925-1, 2014b.

CHEBRO: Mapa "Fondos Aluviales" 1 : 50000, available at: http: //www.oph.chebro.es/ContenidoCartoGeologia.htm (last access: 10 August 2006), 1993.

CHEBRO: Usos de Suelos (1984/1991/1995) de la cuenca hidrográfica del Ebro; 1 : 100.000, Consultora de M. Angel FernándezRuffete y Cereyo, Oficina de Planificación Hidrológica, C.H.E., available at: http://oph.chebro.es/ (last access: 1 March 2006), 1998.

CHEBRO: Evolución de la temperatura y la precipitación en la cuenca del Ebro, available at: http://www.chebro.es/contenido. streamFichero.do?idBinario=16419 (last access: 11 June 2018), 2012.

Couch, A., Hooper, R., Pollak, J., Martin, M., and Seul, M.: Enabling water science at the CUAHSI water data center, in: Proceedings, 7th International Congress on Environmental Modelling and Software: Bold Visions for Environmental Modeling, iEMSs 2014, San Diego, California, USA, 15-19 June 2014, 1, 1-8, available at: http://former.iemss.org/sites/ iemss2014/proceedings.php (last access: 24 March 2017), 2014.

de Vente, J., Poesen, J., Bazzoffi, P., Van Rompaey, A., and Verstraeten, G.: Predicting catchment sediment yield in Mediterranean environments: the importance of sediment sources and connectivity in Italian drainage basins, Earth Surf Process Landforms, 31, 1017-1034, https://doi.org/10.1002/esp.1305, 2006. 
Fargas, D., Martínez-Casasnovas, J. A., and Poch, R.: Identification of Critical Sediment Source Areas at Regional Level, Phys, Chem, Earth, 22, 355-359, 1997.

Foerster, S., Wilczok, C., Brosinsky, A., and Segl, K.: Assessment of sediment connectivity from vegetation cover and topography using remotely sensed data in a dryland catchment in the Spanish Pyrenees, J. Soils Sediments, 14, 1982-2000, https://doi.org/10.1007/s11368-014-0992-3, 2014.

Foerster, S., Brosinsky, A., Wilczok, C., and Bauer, M.: Isábena 2011 - An EnMAP Preparatory Flight Campaign (Datasets), https://doi.org/10.5880/enmap.2015.007 (last access: 11 June 2018), 2015.

Francke, T., Werb, S., Sommerer, E., and López-Tarazón, J. A.: Analysis of runoff, sediment dynamics and sediment yield of subcatchments in the highly erodible Isábena catchment, Central Pyrenees, J. Soils Sediments, 14, 1909-1920, https://doi.org/10.1007/s11368-014-0990-5, 2014.

Francke, T., Foerster, S., Brosinsky, A., Sommerer, E., LópezTarazón, J. A., Güntner, A., Batalla, R., and Bronstert, A.: Hydro-sedimentological dataset for the mesoscale mountainous Isábena catchment, NE Spain, V. 2.0, GFZ Data Services, https://doi.org/10.5880/fidgeo.2018.011 (last access: 11 June 2018), 2018.

García-Ruiz, J. M., Beguería, S., López-Moreno, J. I., Lorente, A., and Seeger, M.: Los recursos hídricos superficiales del Pirineo aragonés y su evolución reciente, Logroño, Spain, 2001.

Goodrich, D. C., Keefer, T. O., Unkrich, C. L., Nichols, M. H., Osborn, H. B., Stone, J. J., and Smith, J. R.: Longterm precipitation database, Walnut Gulch Experimental Watershed, Arizona, United States, Water Resour Res, 44, W05S04, https://doi.org/10.1029/2006WR005782, 2008.

Horsburgh, J. S., Tarboton, D. G., Maidment, D. R., and Zaslavsky, I.: A relational model for environmental and water resources data, Water Resour. Res., 44, W05406, https://doi.org/10.1029/2007WR006392, 2008.

Kadlec, J., StClair, B., Ames, D. P., and Gill, R. A.: WaterML $\mathrm{R}$ package for managing ecological experiment data on a CUAHSI HydroServer, Ecol. Inform., 28, 19-28, https://doi.org/10.1016/j.ecoinf.2015.05.002, 2015.

Le Coz, J., Renard, B., Bonnifait, L., Branger, F., and Le Boursicaud, R.: Combining hydraulic knowledge and uncertain gaugings in the estimation of hydrometric rating curves: A Bayesian approach, J. Hydrol, 509, 573-587, https://doi.org/10.1016/j.jhydrol.2013.11.016, 2014.

López-Tarazón, J. A. and Batalla, R. J.: Dominant discharges for suspended sediment transport in a highly active Pyrenean river, J Soils Sediments, 14, 2019-2030, https://doi.org/10.1007/s11368-014-0961-x, 2014.

López-Tarazón, J. A., Batalla, R. J., Vericat, D., and Francke, T.: Suspended sediment transport in a highly erodible catchment: The River Isábena (Southern Pyrenees), Geomorphology, 109, 210-221, https://doi.org/10.1016/j.geomorph.2009.03.003, 2009.

López-Tarazón, J. A., Batalla, R. J., Vericat, D. and Balasch, J. C.: Rainfall, runoff and sediment transport relations in a mesoscale mountainous catchment: The River Isábena (Ebro basin), Catena, 82, 23-34, https://doi.org/10.1016/J.CATENA.2010.04.005, 2010.
López-Tarazón, J. A., Batalla, R. J., Vericat, D., and Francke, T.: The sediment budget of a highly dynamic mesoscale catchment: The River Isábena, Geomorphology, 138, 15-28, https://doi.org/10.1016/j.geomorph.2011.08.020, 2012.

MARM: Mapa de cultivos y aprovechamientos $1: 50000$, Ministerio de Medio Ambiente, y Medio Rural y Marino, 2008.

Mueller, E. N., Güntner, A., Francke, T., and Mamede, G.: Modelling sediment export, retention and reservoir sedimentation in drylands with the WASA-SED model, Geosci. Model Dev., 3, 275-291, https://doi.org/10.5194/gmd-3-275-2010, 2010.

Nichols, M. H., Stone, J. J., and Nearing, M. A.: Sediment database, Walnut Gulch Experimental Watershed, Arizona, United States, Water Resour. Res., 44, W05S06, https://doi.org/10.1029/2006WR005682, 2008.

Nord, G., Boudevillain, B., Berne, A., Branger, F., Braud, I., Dramais, G., Gérard, S., Le Coz, J., Legoût, C., Molinié, G., Van Baelen, J., Vandervaere, J.-P., Andrieu, J., Aubert, C., Calianno, M., Delrieu, G., Grazioli, J., Hachani, S., Horner, I., Huza, J., Le Boursicaud, R., Raupach, T. H., Teuling, A. J., Uber, M., Vincendon, B., and Wijbrans, A.: A high space-time resolution dataset linking meteorological forcing and hydro-sedimentary response in a mesoscale Mediterranean catchment (Auzon) of the Ardèche region, France, Earth Syst. Sci. Data, 9, 221-249, https://doi.org/10.5194/essd-9-221-2017, 2017.

Peart, M. R. and Walling, D. E.: Title Fingerprinting sediment source?: the example of a drainage basin in Devon, UK, in: Drainage basin sediment delivery: proceedings of a symposium, Albuquerque, NM, 4-8 August 1986, 41-55, 1986.

Pelletier, P. M.: Uncertainties in the single determination of river discharge: a literature review, Can. J. Civil Eng., 15, 834-850, https://doi.org/10.1139/188-109, 1988.

Reusser, D. E., Buytaert, W., and Vitolo, C.: RHydro - Hydrological models and tools to represent and analyze hydrological data in $\mathrm{R}$, in Geophysical Research Abstracts, EGU General Assembly, Vienna, Austria, 22-27 April 2012, EGU2012-4166, 2012.

Rottler, E., Francke, T., and Gafurov, A.: Implementation of a snow routine into the hydrological model WASA-SED and its validation in a mountainous catchment, EGU General Assembly, Vienna, Austria, 8-13 April 2018, EGU2018-12224, 2018.

Savitzky, A. and Golay, M. J. E.: Smoothing and Differentiation of Data by Simplified Least Squares Procedures., Anal Chem, 36(8), 1627-1639, https://doi.org/10.1021/ac60214a047, 1964.

Smith, H. G. and Blake, W. H.: Sediment fingerprinting in agricultural catchments: A critical re-examination of source discrimination and data corrections, Geomorphology, 204, 177-191, https://doi.org/10.1016/j.geomorph.2013.08.003, 2014.

Stone, J. J., Nichols, M. H., Goodrich, D. C., and Buono, J.: Long-term runoff database, Walnut Gulch Experimental Watershed, Arizona, United States, Water Resour. Res., 44, 5-5, https://doi.org/10.1029/2006WR005733, 2008.

Verdú, J. M., Batalla, R. J., and Martínez-Casasnovas, J. A.: Estudio hidrológico de la cuenca del río Isábena (Cuenca del Ebro). I: Variabilidad de la precipitación, Ingeniería del Agua, 13, 321330, 2006.

Westerberg, I., Guerrero, J. L., Seibert, J., Beven, K. J., and Halldin, S.: Stage-discharge uncertainty derived with a non-stationary rating curve in the Choluteca River, Honduras, Hydrol. Process., 25, 603-613, https://doi.org/10.1002/hyp.7848, 2011. 